\title{
Učitelské kompetence pro inkluzivní vzdělávání žáků v základních školách
}

\section{Teachers Competent for Inclusive Education of Pupils at Grammar Schools}

Petr Franiok, Katedra speciální pedagogiky, Ostravská univerzita, Ostrava

\section{Abstrakt}

Příspěvek se zabývá zkušenostmi z posledních tří let řešení projektu OP VVV Vytvoření sítě inkluzivních škol v Moravskoslezském a Zlínském kraji (2017-2020) s dopadem na utváření učitelských kompetencípro inkluzivní vzdělávání žákủ se speciálními vzdělávacími potřebami.

\section{Klíčová slova}

Inkluzivní škola, žák se speciálními vzdělávacími potřebami, učitelská kompetence

\section{Abstract}

The Teachers Competences for Inclusive Education of Pupils with Special Educational Needs.

The article is focused on experiences of project „Creating of Network of Inclusive Schools at Moravian-Silesian Region and Zlin Region“ (2017-2020) and impact to teachers competences for eduaction of pupils with special educational needs.

\section{Keywords}

inclusive school, pupils with special educational needs, teachers competence

\section{Úvod}

Od listopadu roku 2017 byla Pedagogická fakulta Ostravské univerzity řešitelem projektu Operačního programu Evropské unie Výzkum, vývoj a vzdělávání pod názvem Vytvoření sítě inkluzivních škol v Moravskoslezském a Zlínském kraji (registrační číslo: CZ.02.3.62/0.0/0.0/16_037/0003971). Na řešení projektu se zásadním zpo̊sobem podílela Katedra speciální pedagogiky Pedagogické fakulty Ostravské univerzity s podporou projektového oddělení Pedagogické fakulty. Řešitelský tým na Pedagogické fakultě OU tvořili: doc. PaedDr. Petr Franiok, Ph.D. - odborný řešitel, spoluřešitelé: PhDr. Petr Adamus, Ph.D., Mgr. Igor Hampl, Ph.D., Mgr. Daniela Kilduff, Ph.D., Mgr. Iva Klugová, Ph.D., PaedDr. Renata Kovářová, Ph.D., Mgr. Hana Novohradská - členové Katedry speciální pedagogiky. Řešitelský tým byl rozšířen o spoluřešitele v terénu: pedagogičtí pracovníci v centrech kolegiální podpory, lektoři, metodici. Projekt byl zaměřen na posílení kompetencí učitelů základních škol pro práci s žáky se speciálními vzdělávacími potřebami a vytvoření podmínek pro jejich vzájemné učení.

\section{Přístup k řešení}

Řešení projektu započalo na podzim roku 2017 dvěma workshopy, které svolal řešitel projektu doc. Petr Franiok a na kterých se setkal kompletní řešitelský tým tvořený pracovníky Katedry speciální pedagogiky PdF OU s kolegy, kteří zabezpečovali chod čtyř center kolegiální podpory, která byla rozmístěna na území dvou krajů (Moravskoslezský, Zlínský), a to v Ostravě, Zlíně, Valašském Meziř̌ičí a v Opavě. Od ledna 2018 se konala pravidelná měsíční setkání s učiteli zasít́ovaných škol (v průběhu řešení projektu byl 
zaregistrován zájem celkem 143 učitelo̊) v centrech kolegiální podpory, která byla vytvořena v základních školách uvedených čtyř měst. Vedle pravidelných měsíčních setkání v centrech kolegiální podpory s učiteli zasítovaných základních škol probíhaly v rámci řešení projektu také další aktivity související s inseminací podpory inkluzivního vzdělávání žáků se speciálními vzdělávacími potřebami.

V průběhu tří let se konaly rovněž aktivity, které souvisely s posílením koheze řešitelského týmu. Šlo především o šest workshopů konaných na různých místech Moravskoslezského kraje a zahraniční stáž spojenou s výměnou zkušeností s inkluzivním vzděláváním žáků se speciálními vzdělávacími potřebami (Sofie, 2019). Zejména v základních školách, jejichž učitelé byli zapojeni do projektu, probíhaly osvětové aktivity, které garantovali pracovníci čtyř center kolegiální podpory. Aktivity měly za cíl informovat zejména rodičovskou veřejnost o řešeném projektu a zvyšovat povědomí veřejnosti o inkluzivním vzdělávání v základních školách.

Z hlediska řízení a postupu řešení uvedeného projektu měly značný význam zejména jednodenní či výjezdní dvoudenní workshopy. Workshopů se účastnili kromě řešitelského týmu tvořeného převážnou části pracovníků z Katedry speciální pedagogiky rovněž pedagogičtí pracovníci (ředitel školy - kouč, vedoucí centra kolegiální podpory, zástupce vedoucího) ze čtyř základních škol, kteří utvářeli v rámci projektu tzv. centra kolegiální podpory (místa, kde dochází k setkávání učitelů z okolních škol (zasítovaných škol) a následnému předávání zkušeností při vzdělávání žáků se speciálními vzdělávacími potřebami. Na začátku řešení projektu se konaly dva jednodenní workshopy, které souvisely s rozběhem projektu a přípravou aktivit (zejména setkání s učiteli), které probíhaly od ledna 2018 v každém ze čtyř center kolegiální podpory. Cílem dvoudenních workshopů bylo jednak zhodnocení dosavadního průběhu realizace projektu a také příprava obsahu a harmonogramu setkání učitelů zasítovaných škol v následujícím školním roce, kdy pravidelná měsíční setkání v centrech kolegiální podpory vždy probíhala za výrazného přispění zainteresovaných učitelů z center nebo dalších učitelů kooperujících zasítovaných škol. Workshopy byly pozitivně hodnoceny ze strany zúčastněných pedagogických pracovníků center kolegiální podpory a také ze strany členů odborného týmu projektu. Vedle podrobného harmonogramu setkání pro další školní rok šlo na workshopech v neposlední řadě o hledání a vymezení obsahu jednotlivých setkání a v případech určitých vybraných témat také o přizvání externích lektorů, kteří facilitovali téma učitelům ze škol zejména po stránce metodické.

Ve druhé části řešení projektu došlo rovněž na témata, která nebyla v návrhu řešení zcela zřejmá. Byla považována spíše za přidruženou záležitost. Šlo zejména o témata související s výchovnými problémy žáků se speciálními vzdělávacími potřebami. Po celou dobu řešení projektu byla diskutována otázka, kterou sice odborný tým předpokládal, avšak nepovažoval tuto jednoznačně za zásadní. Šlo o spolupráci rodiny a školy v případech žáků se speciálními vzdělávacími potřebami.

Projekt, jeho hlavní myšlenky a cíle i aktuální průběh jeho řešení, byl několikrát propagován v různých mediích. Připomínáme zde počiny, které přispěly ke zvýšení povědomí české veřejnosti o smyslu a přínosech projektu a pro odbornou veřejnost měly spíše infomační charakter:

- Příspěvek na mezinárodní konferenci pořádané Slezskou univerzitou v Katovicích (Polsko), kde spoluorganizátorem byla Katedra speciální pedagogiky Pedagogické fakulty Ostravské univerzity, s názvem „Bilans zysków i strat“ v Ustroni 16.-17. 4. 2018: FRANIOK Petr: Wybrane konsekwencje edukacji inkluzyjnej w Republice Czeskiej. V příspěvku, který bude následně publikován ve sborníku z mezinárodní konference, autor informoval o aktuálně řešeném projektu OP Výzkum, vývoj a vzdělávání a použil dílčí data získaná v prvních měsících řešení projektu.

- Vystoupení na národní konferenci pořádané Psychopedickou společností a Logopedickou společností Miloše Sováka, kterou zaštítila 1. místopředsedkyně Senátu Parlamentu CR Miluše Horská, s názvem „Podpora dětí a žáků se speciálními vzdělávacími potřebami“ v Praze (Senát Parlamentu ČR, 15. 5. 2018). Franiok Petr, předseda Psychopedické společnosti, v úvodu vystoupil s informacemi o aktuálně řešeném projektu Pedagogickou fakultou Ostravské univerzity Vytvoření sítě inkluzivních škol v Moravskoslezském a Zlínském kraji a dále vystoupil jako spoluautor příspěvku JANKŮ, K., FRANIOK, P.: Problematika kombinovaného postižení v současnosti. V př́íspěvku autoři zmiňují řešený projekt Vytvoření sítě inkluzivních škol v Moravskoslezském a Zlínském kraji.

- Vystoupení v televizi NOE dne 20. února 2019 v pořadu Živě s NOE. Hodinový pořad, jehož hlavním mottem bylo připomenutí výročí prof. Rudolfa Jedličky a jeho práce s dětmi v Jedličkově ústavu v Praze, kdy uskutečňoval již na začátku 20. století integraci - inkluzi dětí s tělesným postižením v zájmových činnos- 
tech. Řešitel projektu upozornil na paralelu s aktuálně řešenými problémy českého školství a informoval o řešeném projektu OP VVV Vytvoření sítě inkluzivních škol v Moravskoslezském a Zlínském kraji.

- Příspěvek na národní konferenci pořádané Psychopedickou a Logopedickou společností s názvem Mezirezortní spolupráce dne 22. května 2019 na Pedagogické fakultě Univerzity Karlovy v Praze, kde spoluorganizátorem byla Katedra speciální pedagogiky Pedagogické fakulty Ostravské univerzity. FRANIOK Petr: Mezirezortní spolupráce a inkluzivní vzdělávání v rámci projektu OP VVV Vytvoření sítě inkluzivních škol v Moravskoslezském a Zlínském kraji.

Další klíčovou aktivitou projektu bylo shromáždění příkladů dobré praxe. Příklady dobré praxe byly shromažd'ovány v průběhu celé doby řešení projektu. Projekt startoval s určitými př́lklady dobré praxe, které byly součástí Žádosti o podporu. Uvedené příklady dobré praxe byly jednak prezentovány a jednak dále rozvíjeny, aplikovány na základě poznatků a zkušeností pracovníků center kolegiální podpory a učitelo̊ zasítovaných škol, ke kterým byla tzv. bagatelní podpora směrována. Příklady dobré praxe byly průběžně doplňovány a částečně inovovány také na základě aktuálního stavu žáků ve třídách, kteří představují předobraz dobré praxe a kteří se v průběhu školního roku spontánně vyvíjejí a pro každý další školní rok nutně vyžadují dílčí úpravy, které se promítly do sledovaných příkladů dobré praxe. Příklady dobré praxe byly v některých případech použity při tvorbě metodik práce pro inkluzivní vzdělávání žáků s různými typy speciálních vzdělávacích potřeb. Šest metodik zaměřených na inkluzivní vzdělávání žáků se speciálními vzdělávacími potřebami vyšlo ve třetím roce řešení projektu tiskem. Uvedené metodiky byly určeny právě učitelưm, kteří splnili celou bagatelní podporu, tzn. zúčastnili se nejméně 40 hodin setkání. Samotnými učiteli je oceňován zejména tzv. baliček didaktických pomůcek, který je určen především (byt' ne pouze) pro práci v inkluzivní třídě pro žáky s různými typy speciálních vzdělávacích potřeb.

Zahraniční stáže pro pedagogické pracovníky podílející se na řešení projektu tvořily jednu z aktivit projektu. Jejich realizace byla od začátku zamýšlena jako určitý bonus. S ohledem na pandemii a následná opatření proti šírení koronaviru covid-19 od března roku 2020 byla realizována (do doby vypuknutí pandemie) pouze jedna zahraniční stáž, které se účastnilo 10 členů širšího řešitelského týmu. Příprava a zajištění představovalo značné úsilí zejména ze strany řešitele projektu, když uvážíme, že šlo o přímé vstupy do škol poskytujících základní vzdělání a monitorování průběhu výuky žáků se speciálními vzdělávacími potřebami v těchto školách. V případě zahraniční stáže šlo o vybrané základní školy v Sofii. Již v průběhu řešení projektu vstoupilo v platnost opatření EU - GDPR, které značně svazovalo možnosti přímého vstupu do vyučování i pro zahraniční - hospitující návštěvníky (učitele). Protože základní řešitelský tým pocházel z akademického prostředí, byl řešitel odkázán na spolupráci s akademickým prostředím v zahraničí a přes Univerzitu sv. Klimenta Ochridského v Sofii bylo umožněno účastníkům stáže vstoupit do škol poskytujících základní vzdělání, které ovšem netvoří součást akademického prostředí v dané zemi, nýbrž jsou řízeny místními samosprávami.

\section{Výsledky}

0 účast v projektu byl mezi učiteli základních škol značný zájem. V průběhu tří let řešení projektu byl registrován zájem (vždy podpořený účastí na několika setkáních v centrech kolegiální podpory) 143 učitelů. Do konce doby řešení projektu splnilo tzv. bagatelní podporu 112 učitelů různých základních škol v Moravskoslezském a Zlínském kraji. Pro úplnost je nutné zmínit prodloužení doby řešení projektu o tři měsíce. Prodloužení doby řešení bylo nezbytné z důvodu uzavření základních škol v rámci protiepidemických opatření. Učitelé se splněnou bagatelní podporou (zejména 40 hodin setkání v centrech kolegiální podpory) obdrželi balíčky didaktických pomůcek (každý v hodnotě 21 tisíc Kč). Speciální pomůcky jsou určeny pro vzdělávání žáků se speciálními vzdělávacími potřebami. Za žáky se speciálními vzdělávacími potřebami byli pro účely projektu považováni žáci se specifickými poruchami učení, narušenou komunikační schopností, sluchovým a zrakovým postižením, mentálním postižením a poruchami autistického spektra. V projektu nešlo o vyčerpávající výčet všech druhů speciálních vzdělávacích potřeb. Jejich výběr byl formulován poskytovatelem dotace (MŠMT).

\section{Závěr}

Deklarovaným projektovým záměrem bylo přispět k řešení problémů spojených s vytvořením podmínek 
pro vzájemné učení pedagogů - učitelů s rozdílnými zkušenostmi. Projektový záměr přispěl k naplnění strategie podpůrných opatření pro plnohodnotné vzdělávání v souladu s Akčním plánem inkluzivního vzdělávání na léta 2016-2020 a Úmluvou o právech osob se zdravotním postižením. Cílem osvětových aktivit v rámci zasítovaných škol bylo zpř́stupnit myšlenku inkluzivního vzdělávání širší veřejnosti. Aktivity byly zacíleny rovněž na překonání bariér ze strany širší veřejnosti (zejména zákonných zástupců žáků základních škol, širší veřejnosti v místě konání osvětových akcí), které v některých případech stále tvoří překážku pro přijetí konceptu inkluze, posílení prosociálního chováník žákủm s různými druhy speciálních vzdělávacích potřeb. Uvedené podmínky jsou vnímány jako nezbytné pro efektivní proces inkluzivního vzdělávání v prostředí běžných ZŠ, podporu profesionální připravenosti projektu se účastnících učitelů ZŠ, podporu připravenosti dalších učitelů v uvedených školách. Cílem uvedených aktivit bylo narušit bariéru a předsudky, které brání plnému přijetí konceptu inkluzivního vzdělávání v českém školství.

\section{Literatura}

Akční plán inkluzivního vzdělávání na léta 2016-2020. (2016). Praha: MŠMT.

Franiok, P. (2018). Wybrane konsekwencje edukacji inkluzyjnej w Republice Czeskiej. In Bilans zysków i strat. Ustroń, 16.-17. 4. 2018.

Strnadová, I., Hájková, V. (2010). Inkluzivní vzdělávání. Praha: Portál.

\section{Autor}

doc. PaedDr. Petr Franiok, Ph.D.

Katedra speciální pedagogiky

Ostravská univerzita - Pedagogická fakulta

E-mail: petr.franiok@osu.cz

Autor se dlouhodobě zabývá problematikou vzdělávání žáků s mentálním postižením, speciálně pedagogickou diagnostikou a muzikoterapií. 